\title{
Hamlet on the Screen
}

Prof. Essam Fattouh*

English Department, Faculty of Arts, University of Alexandria (Egypt)

DOI: $10.36348 /$ sijll.2020.v03i04.001 $\quad$ |Received: 20.03 .2020 | Accepted: 27.03 .2020 | Published: 07.04 .2020

*Corresponding author: Prof. Essam Fattouh

Abstract

The challenge of adapting William Shakespeare's Hamlet for the screen has preoccupied cinema from its earliest days. After a survey of the silent Hamlet productions, the paper critically examines Asta Nielsen's Hamlet: The Drama of Vengeance by noting how her main character is really a woman. My discussion of the modern productions of Shakespeare begins with a critical discussion of Lawrence Olivier's seminal production of 1948. The Russian Hamlet of 1964, directed by Grigori Kozintsev, is shown to combine a psychological interpretation of the hero without disregarding its socio-political context. The action-film genre deployed by Franco Zeffirelli in his 1990 adaptation of the play, through a moving performance by Mel Gibson, is analysed. Kenneth Branagh's ambitious and well-financed production of 1996 is shown to be somewhat marred by its excesses. Michael Almereyda's attempt to present Shakespeare's hero in a contemporary setting is shown to have powerful moments despite its flaws. The paper concludes that Shakespeare's masterpiece will continue to fascinate future generations of directors, actors and audiences.

Keywords: Shakespeare - Hamlet - silent film - film adaptations - modern productions - Russian - Olivier - Branagh contemporary setting.

Copyright @ 2020: This is an open-access article distributed under the terms of the Creative Commons Attribution license which permits unrestricted use, distribution, and reproduction in any medium for non-commercial use (NonCommercial, or CC-BY-NC) provided the original author and source are credited.

\section{INTRODUCTION}

From the earliest days of cinema, producers and directors have felt driven to meet the challenge of adapting Shakespeare for the screen. Indeed, the very first known cinematic fragment of a silent movie portrays a brief scene of the death of Shakespeare's King John, performed by the famous actor Beerbohm Tree (1852-1917). A version of Richard III is the oldest surviving American full-length film (rediscovered in 1996, and subsequently restored and newly released in 2001)[1].

Unsurprisingly, given its iconic status within the Shakespearean canon, a perennial favourite for such adaptations, has been Hamlet. As we enter the 2020s, the number of Hamlets on screen since 1900 totals nearly fifty. Each of these filmed versions is both a translation and an interpretation of Shakespeare, always governed by the director's vision, plus that of a host of technicians - camera operators, script consultants, designers and editors. Then there is the actor's interpretation - the ability to bring individuality to a given role, in creative interaction with other members of the cast. The film will have been conditioned, too, and sometimes limited, by the technical capacities of a given time period.
Before examining the various avatars in which this most compelling and intriguing of all Shakespeare's plays has appeared on screen, it seems worth considering in general terms, the constraints that the Elizabethan and Jacobean stage imposed on Shakespeare's fertile imagination. Arguably cinema, in overcoming such constraints, provides new scope for exploration of the contents of his extraordinary mind.

Settings on the theatre stage, no matter how colourful, are inevitably somewhat static, and as such may easily become a distraction from the imaginative world conjured up by Shakespeare's words. The playwright himself was aware of the severe limitations of his contemporary theatrical technology, shorn as it was even of the possibility of lighting effects, or much in the way of sound effects. The electronically-based techniques of twenty-first century drama productions are resources he could only have dreamed of.

The modern theatre has rectified at least one lack that existed for Shakespeare. In his own theatre he could not use women to portray his Gertrude or Ophelia, or the fascinatingly complex figures of his Cleopatra and Lady Macbeth, having had instead to rely on male actors to perform these parts. The lack of 
realism in this respect must have been a further source of frustration.

We know he felt the limitations, from the apologetic words of the Chorus, in the opening scene of Henry $V$ :

But pardon ...

The flat unraised spirits that have dared On this unworthy scaffold to bring forth So great an object: can this cockpit hold The vasty fields of France? or may we cram Within this wooden $\mathrm{O}$ the very casques That did affright the air at Agincourt? .... Piece out our imperfections with your thoughts ... [2]

In the conventional theatre, transitions from scene to scene - whether with accompanying darkening of the stage, or done in broad daylight with the shuffling in and out of stagehands bearing pieces of furniture - may, however skilfully done, disrupt the flow of performance, and distract the audience from the action of the play. Cinema, on the other hand, can maintain narrative flow more or less seamlessly from scene to scene, in a way Shakespeare no doubt would have loved. Cinema allows constant split-second shifting in both time, as well as in space. A director wishes, for instance to dramatize Prospero's tale to his daughter, of his brother's past usurpation of the kingdom, and their shipboard journey into exile, with Miranda as a weeping small child. Nothing is easier than to interpolate a visual version of the remembered scene - lasting only a few seconds, perhaps; but bringing the haste, the shock and grief of the moment, vividly to life. Or the film can cut rapidly between the bright, sunlit court of Cleopatra, with its colourful eastern decadence, and the more austere, sombre world of Octavius in Rome.

As John Danby pointed out in a vivid account of Antony and Cleopatra, published in 1952 (1965), four years after Laurence Olivier's screen version of Hamlet: 'To describe the swiftness of Antony and Cleopatra we need to draw on the imagery of the cinema'. Danby comments on the play's technique of 'cinematic movement', with its'panning, tracking', and 'playing with the camera' [3]. Shakespeare would certainly have made use of the cinematic medium, had it been available to him.

His world is animated by supernatural apparitions - ghosts, fairies, and spirits of a haunted island in The Tempest - figures that the special effects of cinema can animate vividly and credibly, way beyond what the resources of theatre can achieve. Moreover, in common with other Elizabethans, Shakespeare loved pageantry and spectacle. The arrival of a monarch at his palace, with all his nobles and courtiers in tow; the passage of an army through open country, to clash violently with an opposing force; shipwreck, or the onslaught of an angry mob, are all more easily evoked by the mobilisation on set, of a crowd of extras such as no theatre could hope to contain.

Such crowd scenes can direct the audience swiftly from the general to the particular - may, from a wide or panning shot of a joyously dancing crowd, home in on specific details of the scene - an animating close-up of an individual face, or a brief glimpse of an interaction between two individuals within the broader panorama.

Where, visually speaking, theatre relies mainly on movements and gestures of the whole body, cinema can offer compelling insight into the psychology of an individual via the close-up. Primitive techniques of the earliest films, that predated the use of close-ups, have been rendered obsolete. To offer but one example, an early technical device portrayed Hamlet's hair literally standing on end at the sight of his father's ghost. The sophisticated art of trained actors, exposed to the searching scrutiny of modern cameras, can now show us a whole gamut of complex emotions shifting across the living canvas of the human face. Indeed, the credibility of any actor who lacks the requisite interiority in close-up performance is likely to suffer badly.

Cinema allows, too, for highly imaginative meta-interpretation of Shakespeare; as in a work like Peter Greenaway's Prospero's Books 1991, with its multiple dreamlike visual unfoldings, in which Shakespearean drama joins hands with surrealism. In tracing the history of Hamlet on screen, however, we need to examine more modest beginnings in adapting Shakespeare for the movies - in the first tentative experiments in the early twentieth century in the heyday of silent films.

The earliest silent version of the play (and one of the first silent movies ever made), is the production by Georges Méliès, in 1907. It was followed in 1908, by a Hamlet directed by Luca Comerio. Other silent films of Hamlet were directed by William George Barker and August Blom, both in 1910. There was a production by Cecil Hepworth, in1913, directed by Hay Plumb; and a new silent version by Eleuterio Rodolfi [4].

What we notice about these early silent Hamlets is the degree to which, as in other performances on silent film, the cinematic versions in their acting styles retain the conventions of the stage large dramatic gestures, originally intended to be seen clearly from the back of a crowded auditorium; stylised, sweeping movements - outflung arms, heads plunged deep into outspread palms; clasped hands lifted high and shaken at the heavens, to denote shock, anger, joy, grief, etc. Presumably, apart from the fact that early 
cinematic actors had all been trained in these histrionic manners of stage acting, early film technology could not, as previously mentioned, yet handle close-ups. Even when homing in on a single character (as for example in one of Hamlet's soliloquies), the camera takes in the character's whole body rather than, as we might expect, closing in on the face. Given that the performance in these early movie versions has quite literally, lost its voice, the significance of bodily gesture is doubly heightened. Indeed, the audience is often compelled to follow the action and interaction between characters, by mere snippets of dialogue, pasted onto the screen as subtitles at widely spaced intervals. Anyone in the cinema audience unfamiliar with the plot of Hamlet would be puzzled as to what is really going on.

Early silent Hamlets tended to be heavily edited versions of the original Shakespeare text, and correspondingly short in duration. A film 'adaptation' from 1900 lasts precisely two minutes. The aim of such versions was simply to give a recognisable visual image of Shakespeare's hero, while affording a starring part to the actor playing Hamlet; usually one who had previously played the role on stage. The films are quick-paced, and attempt to substitute action for words, favouring energetic, violent scenes such as duels, over the play's soliloquies. Death scenes are done in exaggerated detail - milked for images of melodramatic agony [4].

One advantage that the earliest directors quickly seized on was the opportunity in cinema to open out the action, to take scenes that formerly could only be staged in the enclosed space of a theatre, out of doors. There is a scene in Hay Plumb's Hamlet of 1913, for instance, where the prince (played by Johnston Forbes-Robertson), follows his father's ghost away from the ramparts of Elsinore to a confrontation on a rocky beach with a vista of cliffs in the background. The encounter on the shore offers contrast and relief particularly as it follows directly after a claustrophobic scene in the throne room at Elsinore - and realism to the setting. It also - in spite of the rather too corporeal image of the screen ghost - lends credibility to the warnings from Hamlet's companions, about following the ghost too far from the safety of the castle ramparts.

With the passage of time, adaptations of Hamlet for the cinema would become more adventurous. What follows is a discussion of six of these screen adaptations, chosen to illustrate the sheer diversity of possible approaches.

\section{Svend Gade and Heinz Schall}

One controversial silent production, that for its startling originality - not to say eccentricity - stands out from the common run of silent Hamlets, is the 1921 version entitled Hamlet: the Drama of Vengeance [5]. A German production, that had its first screening in
Finland, this co-directed film stars the Danish film actress Asta Nielsen (1881-1972), who starred in over seventy films. One of the most popular leading ladies of the 1910s - and one of the first movie stars to enjoy an international reputation - Nielsen was not the first female actor to take up the role of Hamlet, which Sarah Bernhardt (1844-1923) had enacted in 1900 (in a stage performance recorded on audiotape). The difference between Bernhardt's performance and Nielsen's is that the latter plays a female Hamlet, who has disguised herself as a man [6]. The screenplay, by Erwin Gepard, is inspired by Edward P. Vining's book The Mystery of Hamlet (1881), in which Vining argues that Hamlet's personality, as portrayed by Shakespeare, suggests that she is really a woman [7].

In the convoluted plot of Hamlet: the Drama of Vengeance, Hamlet is disguised as a man so that the patrilineal succession to the throne of Denmark may be preserved, in the absence of a male heir. As in the original Hamlet, the protagonist becomes a scholar in Wittenberg, where she feels alienated, living isolated from her university colleagues. In a caption to the silent film, she is described as having 'clipped wings'. However, she does make friends with Horatio, to whom she is physically and emotionally attracted; and with Fortinbras, who turns out also to be a student at Wittenberg.

Hamlet is shocked to learn of the impending marriage between her mother Gertrude, and her uncle, Claudius. Upon investigation, she concludes that her father has been murdered. Instead of a visitation by the ghost of her father on the Elsinore battlements, she first receives warning of his murder when he visits her in a dream. A gardener at Elsinore later confirms the fact of the murder, and the identity of the killer. In this version, Hamlet's mother Gertrude is equally complicit with Uncle Claudius in the murder of Hamlet's father. As in Shakespeare's play, Hamlet's dilemma is that she lacks the will either to kill Claudius to take revenge for the death of her father, or to kill herself.

Hamlet becomes jealous of Ophelia, when she learns that Horatio, who has accompanied her, on her return to Elsinore, has fallen in love with the young woman. In order to distract Ophelia from her interest in Horatio, Hamlet herself successfully woos her, declaring 'Now, Horatio, you are mine'.

Any remaining doubts of her uncle's crime are dispelled for Hamlet, when Claudius, in panic, interrupts the performance of the play with a plot akin to that of the murder of Hamlet's father. Now fully convinced of Claudius' guilt, she rushes to his room, sword in hand, only to find him praying; whereupon she desists. She does, however, as in Shakespeare, accidentally stab to death Ophelia's father Polonius in mistake for Claudius. Claudius' plan to send Hamlet to Norway, there to have Hamlet killed by Fortinbras, fails 
when Hamlet substitutes a new letter for that carried by the messengers escorting her to Norway, having them executed in her stead.

Hamlet reappears at Claudius' court, where she finds him carousing with his entourage. (Ophelia has in the meantime gone mad with grief at her father's death, and committed suicide.) Hamlet sets fire to the room where Claudius and his drunken companions are seated, leaving them to burn to death. Gertrude conspires with Laertes to take revenge on Hamlet - as in Shakespeare - via the device of a fencing tournament and a poisoned rapier, followed by a cup of poisoned wine. After Laertes and Hamlet destroy one another in the duel, and Gertrude accidentally drinks the poison intended for her daughter, Horatio rushes to Hamlet's side, and begins to unbutton his friend's shirt to tend her wound. Hamlet collapses, dying, as the realisation for the first time dawns on Horatio, that Hamlet was a woman. He kisses Hamlet's lips, vowing for ever to keep his friend's secret. Fortinbras then arrives on the scene, and commands that Hamlet be buried with the honours of a military funeral.

Nielsen's performance as Hamlet proved seminal in transforming the interpretation of the character, from highly theatrical, even melodramatic, to a more naturalistic style, paying attention to facial expression and subtleties of emotion generally. This unique interpretation of Shakespeare's play has since been restored, and is available to contemporary audiences. It retains its status as one of the most original, if controversial, Hamlets of the silent era.

\section{Laurence Olivier}

By the 1940s, Shakespeare had become a national icon, symbolic of England's cultural gift to the world, and of patriotic cultural values. The British government - and Churchill himself, as Prime Minister and war leader - had supported and promoted Lawrence Olivier's (1907 - 1989) production of Henry V (1944), which Olivier directed, while also playing the leading role. It seemed only fitting that, in the post-war years, he should again star on screen in a Shakespearean role, this time that of Hamlet.

In 1948, when Laurence Olivier both directed and starred in a new film version of Hamlet, he was the actor most closely associated with Shakespearean performance in Britain. Trained at theatre school from an early age, and playing important parts while in his early twenties, Olivier, by the time he came to direct a screen adaptation of Hamlet, had taken the leading role in many stage productions, and also directed performances of others for the stage. He seemed almost predestined to become the first Director of the National Theatre.
Olivier was fully conscious of the cultural and historical significance of his undertaking. His Hamlet is today considered a landmark in the history of Shakespearean screen adaptations, and of cinema as a whole. The film was for many years regarded as the definitive screen adaptation of Hamlet. If that earlier lustre has somewhat faded in the wake of a host of new versions, the fact remains that none of these subsequent productions can afford to ignore Olivier's groundbreaking work.

Unlike Henry $V$ and Richard III, both of which were in colour, the director made a deliberate choice in his Hamlet, to film his version of Shakespeare's play in black and white. Another innovative choice in the Olivier Hamlet lies in the director's conscious adoption of the conventions of film noir Hollywood crime dramas, and of German Expressionist cinema. The purpose is twofold: firstly, to emphasise the play's themes most akin to the murder mystery genre - the investigation of a suspicious death, and the on-going effort to bring the murderer to justice; and secondly, to reflect Hamlet's sombre mood, and the dark preoccupations of his allegedly melancholic temperament.

The whole design of the set is enclosed, labyrinthine, enigmatic and suggestive both of the dark mystery of Hamlet's father's death, and of the psychic labyrinth of Hamlet's mind, as he grapples with private obsessions. The innovative use by camera operator Desmond Dickinson, of a specially designed, highly mobile, camera dolly, enables constant movement through the claustrophobic world of corridors and stairs [8]. The deep contrasts of blackness and light in the shadowy interior world of Elsinore, with the spooky effects of shadows - for example those thrown by torchlight on a wall, as a company of courtiers processes up a staircase - are suggestive both of the doubts that surround the death of Hamlet's father, and of the darkness and confusion of Hamlet's inner state.

The underlying premise of Olivier's interpretation - 'the story of a man who could not make up his mind' - is that Hamlet's irresolution over taking revenge for his father's murder, has arisen because he is emotionally paralysed by his Oedipal fixation on Gertrude his mother, who is deliberately cast as a young-ish woman, played in the film by Eileen Herlie. The incestuous nature of Hamlet's relationship with Gertrude is explicitly foregrounded, both in Olivier's acting performance, and in the heavily Freudian overtones of the set design. This is a version of Hamlet in which Gertrude's bedroom definitely takes precedence over the throne room. We see a shot of the bed in the empty room, well before the climactic scene in which Hamlet confronts his mother over her marriage to Claudius. 
That Olivier drew much of his inspiration for his psychoanalytic interpretation of Hamlet from the work of the distinguished Freudian psychiatrist Ernest Jones is well known. It has, furthermore, been suggested that Oedipal themes had long been a preoccupation of Olivier's, stemming from conflicts that developed with him in early childhood [9]. Whatever personal history may or may not underlie Olivier's interpretation of the key role [10], the fact remains that his Hamlet is likeable and human, and engages our empathy. He is a character with whom an audience can identify.

Olivier's Hamlet won several Academy Awards, and was the first British film to receive one for Best Picture. However, some critics were disparaging regarding as faults the drastic cuts made in Shakespeare's text to reduce the film version to what was regarded as an acceptable cinematic length; and also what some viewed as an overly simplistic interpretation of Hamlet's dilemmas. The influential critic Milton Shulman, for one, wrote in the London Evening Standard, that while some might rate Olivier's film as among the greatest ever made, it would be to others 'a deep disappointment'[11]. While Shulman admired Olivier's performance, calling him 'one of our greatest living actors', he felt compelled to add that he found less to praise about Olivier as a director: 'His liberties with the text ... are sure to disturb many'[11].

A further problem with the Olivier Hamlet is the tendency of the production to become a one-man show. The role of Laertes in the later scenes is considerably muted, as threatening to present a distraction from the dashing swordsmanship of Olivier as Hamlet. In a carry-over from the conventions of the theatre stage, while Olivier constantly moves energetically at the centre of the action, the background of non-speaking extras remains largely static. The courtiers lining the walls in many of the interior scenes neither move nor react with their faces to what is taking place in the scene's foreground.

It should be added, however, that one highly effective innovation in Olivier's film is the use of voice-over to indicate Hamlet's interior monologues, ending with the protagonist speaking the soliloquy's final lines. It was a technique which established a convention for many later screen productions, not only for Shakespearean adaptations, but for screen drama in general.

Whereas the Shakespearean text is at pains to contextualise Hamlet's tragedy in terms of its sociopolitical implications, Olivier deliberately isolates and individualises the protagonist's conflict as a purely personal internal struggle. Significant elements of the original text are, therefore, omitted and ruthlessly truncated - in particular, the movements of Fortinbras across Danish soil, that will end with the latter's assumption of sovereignty in Denmark. A Russian director of the 1960s would take a very different approach to screening Shakespeare's play.

\section{Grigori Kozintsev}

In marked contrast to Olivier's psychoanalytic reading of Hamlet, the screen adaptation of 1964, by the Russian director Grigori Kozintsev, very much focuses on social relations, politics, and questions of power. Interestingly, however, the Russian film borrows certain elements from the opening of Olivier's film notably the close-ups of waves pounding over the rocks around the castle of Elsinore, and the faint tolling of a bell in the darkness, followed by the dark shadows cast by flaming torches on inner walls, as the credits of the Kozintsev film begin to roll. In the Russian Hamlet, however, these images are deployed to very different ends from those of Olivier.

Kozintsev gives us a Hamlet suffering and isolated, feeling himself to be powerless in a crushing tyranny - living under constant surveillance, with growing threats to his life, where even those he loves, seem mostly to have gone over to the enemy and no longer to be trusted. Indeed, the director challenges the prevailing conception of Hamlet as the drama of a man in a state of paralysis, unable to take action owing to some 'fatal flaw' in his personality. For Kozintsev the emphasis lies, rather, 'in the tragedy's provocation to action'. This play, he said once, is 'a tocsin' - an alarm bell - 'that awakens the conscience'. In the corrupt world of Elsinore, 'The characters of the Elsinore story perish from more than physical causes', he writes. 'They were finished long before the poison had gotten into their blood streams from a scratch or a drink' [12].

Of all the Hamlets to appear on the screen, Kozintsev's protagonist, played by Innokenty Smoktunovsky, is the most meditative. This Hamlet projects both an open-minded innocence, and a bitter disillusionment, in the face of a world that fails to live up to his high ideals. The Poloniuses and Claudiuses of that world, meanwhile, gladly pay lip-service to principles they violate in practice. 'To thine own self be true', says Polonius to his son, with unconscious irony, as he willingly serves the corrupt usurper Claudius as snooper and spy.

Paradoxically, despite his grief and bitterness, Kozintsev's Hamlet all the same projects a kind of inner stillness, as in self-contained isolation he moves about the crowded scenes of the Elsinore court, a lonely figure, disregarded in a bustling world. From the first soliloquy, we are presented with a man who is 'in the world, but yet not of it'.

All the same, Hamlet does have to live in the world, and to endure its wrongs. The social framework in which he is forced to exist is, as the film makes explicit, a rigidly hierarchical one, in which the mass of 
the people have no say about decisions taken by the monarchy. The foregrounding of this theme of social inequality is emphasised from the opening scenes. In most productions of Hamlet, Claudius' statement regarding the recent death of his brother the king, and Claudius' marriage to the dead man's widow, is made to a small coterie of courtiers, seated within a throne room. Here, rather, the statement takes the form of a public proclamation, read aloud by a messenger on horseback to a gathered crowd. We are again made aware of the People, and of their lowly status within the social order, at a later moment in the film, when a small group of peasants, come to witness Ophelia's funeral, are roughly driven away from the gravesite by a mounted soldier. When Laertes invades the Elsinore castle to accuse Claudius of responsibility for his father's death, he charges in at the head of an angry crowd of local people. While Claudius pardons the young nobleman, and draws him into his plot to kill Hamlet, we see Laertes' peasant followers arrested and marched away under guard.

It will not escape notice, either, that Hamlet is the one character in Kozintsev's production who disregards social barriers - chatting amicably with the gravedigger he encounters at Ophelia's grave; on terms of equality with two sentries on watch on the Elsinore battlements; and, later in the play, with a troupe of itinerant actors.

In the castle interior, a different aspect of repressive tyranny becomes apparent, with the surveillance laid upon Hamlet by Polonius, incited by the suspicious and insecure Claudius. A world of dark corridors, staircases and wall hangings behind which a watcher may stand concealed, affords ample opportunities for spying. Even the most innocent, like Ophelia, are co-opted into the role of undercover agent. Repression at a personal level is suggested, too, not only in Polonius's patriarchal domination and manipulation of his daughter, but in the heavy corsets and smothering veil imposed on Ophelia as mourning dress after Polonius' death - clothing that she struggles to throw off during the scene of her madness.

The four elements, in this version of Shakespeare's play, almost have a life of their own. The blazing fire in an interior room, where Hamlet is first told of the appearance of his father's ghost, is suggestive of the contained, but always dangerous, energy of an element potentially able to blaze out of control and wreak destruction. The earth is present, not only in Hamlet's dark meditations on death and decay, but in the scene at Ophelia's grave. Air and sky evoke contrasting moods - the dark billowing of the cloak of the ghost of Hamlet's father, silhouetted against the midnight clouds; and the flight of a seabird from the scene of Ophelia's death, to the far-off promontory where Hamlet stands alone. Water is ever-present, not only in the close-up images of waves - suggestive of the overpowering onrush of suppressed emotion pounding and pouring over the rocks below the castle of Elsinore, but in the still water of the river where Ophelia lies drowned.

At the close of Kozintsev's film, we watch as the mortally wounded Hamlet staggers outside the castle walls, to die in the open air. Only in death, it seems, can he ever be free of the stifling prison-palace that had contained him.

The arrival, as Hamlet lies dying, of a new power in the land, seen in the onward march of Fortinbras into Denmark, has several times been glimpsed during the film. These are scenes in keeping with the original Shakespeare text, but that were totally cut from the Olivier production. As Fortinbras enters to claim the Danish throne, Hamlet tells Horatio, 'He has my dying voice' - but really, what alternative choice could there be, other than a possible civil war? And what sort of new ruler is this iron-hard military man likely to be? Yet, the film offers no answers to these questions.

\section{Franco Zeffirelli}

Franco Zeffirelli (1923-2019) made a conscious decision to adopt the action film genre in his 1990 screen adaptation of Hamlet. The average shot length is less than six seconds, making for a fast, and ever-quickening tempo, even though the film actually runs for two and a quarter hours. Shakespearean purists sometimes accuse it of having excessively speeded up the pace of Shakespeare's lines. In doing so, however, Zeffirelli's intention is to convey to an audience the effect of normal speech, while keeping within the bounds of the iambic metre. With a gathering of dramatic pace from an initially slower beginning, the film in its final scenes captures a sense of the headlong rush toward unavoidable tragedy.

Zeffirelli had previously directed an adaptation of Romeo and Juliet (1968) in which he chose a very young and innocent Juliet, with whom a young audience might easily identify, to reintroduce Shakespeare to a new generation. In his Hamlet, he makes a similar choice, in casting Mel Gibson in the leading role. Gibson, then aged 34, was already known for his roles in films like Mad Ma, and Lethal Weapon. It was this dual aspect, of relative youth, and of Gibson's reputation as an action hero, that Zeffirelli aimed to highlight in the character of Hamlet.

Gibson's interpretation of his role in the film will have come as a pleasant surprise to some, who no doubt expected insensitivity from the man best-known for violent action scenes. In fact, he gives a genuinely moving performance, with many nuances and shifts of mood - brooding and introverted in the soliloquies, or with dramatic transitions from manic elation to deep despondency. Gibson's character is an open-hearted 
individual, turned cynical and melancholy by his experiences of the corrupt and violent world of the court of Elsinore that destroys his innocence, and his trust in nearly everyone close to him. Often, he conveys a depth of sorrow that evokes our empathy.

This Hamlet, moreover, has determination and courage as well as sensitivity and wit. In the 'You are a fishmonger' scene he sits perched on an upper shelf in the castle library, wearing only one boot, and with open book in hand, to make fun of the bewildered Polonius. Gibson's lively mockery brings out the full humour of the encounter between the sharply intelligent younger man, and the pompous elderly courtier. We both laugh and applaud as, feigning madness; Hamlet leads the older man ever deeper into verbal paradoxes and mental confusion.

Zeffirelli brings considerable originality to his opening scene, with the gathering of Claudius, Gertrude, and the disaffected and silently enraged Hamlet, around a magnificent tomb, where Hamlet's father lies buried. A close-up of Gertrude's face covered in tears, cuts to the fiercely lustful gaze of Claudius that holds her spellbound, as the latter stares at her down the length of the tomb. In this dramatic visual image, the director gives us the central conflicts of Shakespeare's play - the dead warrior king in his tomb; the living adulterous usurper; the outraged son, whose unenviable mission will be to avenge his murdered father - the three men who, with very different kinds of desire, vie for the love of the same woman.

Zeffirelli follows Olivier in pointing up Hamlet's Oedipal fixation on his mother, played in this production with considerable charm by Glenn Close. The director purposely chose an actor only nine years older than Gibson for the part of Gertrude, and the relative closeness in ages between mother and son gives a highly sensual quality to the bedchamber scene. Hamlet's violent rant against his mother for sleeping with Claudius ends with him kissing her on the mouth.

The overall casting is full of convincing performances. Ophelia (played by Helena Bonham Carter), at first appearance, seems slight and girlish; but her set, resentful expression, as she agrees to her father's command not to encourage further contacts with Hamlet, suggest that she has a mind of her own, even if she is overruled by patriarchal authority. Ian Holm is a splendidly bumbling and fussy Polonius. Paul Scofield's cameo appearance as the ghost brings the expected moment of dread; but also, in the appealing tone of his final injunction to 'Remember me', a touch of pathos.

Much of the action in this Hamlet was filmed in the stunning dramatic location of Dunnottar Castle in Aberdeenshire, Scotland. A contrast is developed between the grey and forbidding atmosphere within
Elsinore's walls, and the verdant world outside. The castle interior is an environment so devoid of plant life or any element of nature, that Ophelia, in her mad scene, when she talks of offering flowers to those surrounding her, can only present them with twigs and bits of straw. The lush greenness of the land around the castle - notably in the scene where Hamlet rides out, and first encounters Rosenscrantz and Guildenstern, comes as a refreshing visual contrast to the grim interior setting.

Throughout the film, Zeffirelli aimed for social realism, deploying a large cast of extras to evoke a medieval world filled with convincing historical detail, from the scrolls and leather-bound books in Elsinore's library, to the nun-like wimples of the female extras. Much of the set design serves purposes beyond that of convincing decoration. Moreover, the skeletons in the castle crypt, form the background to Hamlet's 'To be or not to be?'. The snarling heraldic beast depicted on the wall hangings in Gertrude's room, foreshadows the coming impulsive act of violence when Hamlet runs his sword through the hidden Polonius.

In keeping with the concern for authenticity, the final duel between Hamlet and Laertes is fought with swords and in chain mail, rather than with rapiers, and in fencing gear. This final scene is skilfully done, with a number of original moments - notably the playful behaviour of Hamlet, as he clowns, dodging and feinting, irritating his opponent Laertes, but entertaining his mother; while Glenn Close projects an almost childlike delight in her son's antics.

Gertrude's death, too, is perceptively handled. An attentive audience will be aware, after she swallows the poisoned wine intended for Hamlet, of how quickly Claudius shifts from trying to warn her - 'Gertrude, do not drink' - to ignoring his dying wife. We see him instead intently focussed on the duel, whose outcome will determine whether he can save his own skin. A few seconds later, we have a dramatic close-up on Gertrude's face - too late, she has a sudden flash of understanding that her husband is a murderer.

\section{Kenneth Branagh}

In his 1996 production of Hamlet, Kenneth Branagh, sometimes regarded as the twenty-first century heir to the mantle of Laurence Olivier, realised a life-long dream, of directing and acting in a fulllength, uncut version of Shakespeare's longest play. At 4000 lines, and requiring a full four hours for performance, the work in its complete form calls for stamina, not only from the actors, but even more from an audience. Elizabethans were used regularly to attending three-hour-long sermons, and may well have taken such length in their stride. A twentieth-century audience is no doubt grateful for the invention of digital media and the DVD, in time for Branagh's production [13]. 
Branagh's Hamlet is set in the late nineteenth century, at a time of tensions between interrelated and warring families across Europe. It is a setting which affords scope for sumptuous evening-dress crowd scenes in glittering ballrooms, and scenes of conspiratorial plotting in comfortable-looking, smokefilled studies filled with bookshelves and leather chairs. A small army of extras in nineteenth-century uniforms drilled at Blenheim Palace, which was hired for the occasion, to enact an all-out assault on Elsinore by the troops of Fortinbras.

The supporting cast to Branagh's Prince of Denmark is itself composed of stars, with a fine multifaceted performance by Derek Jacobi as Claudius. The comedian Richard Briers plays Polonius. The film has a powerfully moving Ophelia in Kate Winslet. Julie Christie is a dignified Gertrude. There are cameo performances from Robin Williams as Osric, and Brian Blessed as Hamlet's father's ghost. Although the total cost for the entire production came to a relatively modest $\$ 18$ million, no expense was spared when it came to employing the cream of acting talent.

Branagh worked over every detail of every minor scene - even adding some that either is imaginatively narrated by one of Shakespeare's characters, or that do not occur in Shakespeare's text at all. So, early on in the film, we have a scene where young Fortinbras' elderly uncle learns of his nephew's military escapade in marching on Poland, and summons him back to Norway for a scolding. More surprisingly, Branagh has his Hamlet and Ophelia in bed together something which is warned against by Ophelia's father and brother, but which nothing in Shakespeare's text suggests ever came to pass. The account of the killing of Priam, king of Troy in the presence of his wife Hecuba, vividly told by one of the strolling players on their visit to Elsinore, is quite unnecessarily rendered in visual terms (with a cameo performance by Judi Dench as the distraught queen). In fact, the explicit visual scene undercuts the whole point - that the player's verbal performance alone is so moving; it can draw tears from its hearers, without need of any embellishment. Hamlet wonders how it is that a mere fiction can move an audience, and yet he, in the face of actual personal bereavement and cruel injustice, finds his own heart so cold.

If anything, Branagh's Hamlet suffers from an embarrassment of riches. He never lets the chance go by, to add just one more ingenious touch. The ghost of Hamlet's father makes full use of contemporary special effects, by coming to life from a giant statue on the lawn in front of Elsinore, and stalking across the landscape, opening sulphurously smoking fissures, worthy of a horror film, in the snow-covered ground. Rosencrantz and Guildenstern arrive at Elsinore, not as one might expect in a carriage, but riding on a model train through the palace grounds. Even the grave digger, not content with producing the skull of the jester Yorick, manages to turn up half a dozen more, planting them in a row along the edge of the grave. The dénouement of the duel scene is homage to the era of Hollywood swashbuckling, with a sword fight along the length of an upper gallery, ending with Hamlet tipping Laertes over the balustrade into the hall below. The troops of Fortinbras then crash their way into the palace through its French windows.

The overall obsession with realistic detail does lead to some effective moments. One such moment is where Hamlet, confronted with Ophelia trying to give him back his presents, moves bewildered along a row of opening and closing mirrored doors behind which Polonius and Claudius stand hidden - suspecting the presence of spies, but never able to find them among the shifting images. In a different vein, the performance of the play within a play, and the scenes leading up to it, capture well the mood of a Victorian music hall or theatre for melodrama, suggestive of the world of Dickens. All the same, the overall impression is that Branagh simply does not know where to stop.

The air of excess infects even Branagh's own performance. If anything, he flouts Hamlet's good advice to the players, on restraint in acting: not to 'saw the air with your hand'; not to rant, or 'tear a passion to tatters', but to 'use all gently'. Only in later scenes notably in the graveyard scene and thereafter - does Branagh offer us a more muted, more introspective Hamlet; so that one wonders why he apparently found the ranting performance of the earlier scenes to be necessary.

Both in cinematic presentation, and in the leading man's performance, one can only observe that sometimes, less is more.

\section{Michael Almereyda}

By the director's own admission, Almereyda's film of 1990 owes much of its inspiration to Aki Kaurismaki's deadpan take on Hamlet, Hamlet Goes Business (1987), although entirely without the tonguein-cheek irony and outright farce of Kaurismaki's version [14].

In contrast with the epic glamour of Branagh's Hamlet, Almereyda's twentieth-century adaptation, set in Bill Clinton's America, is a low-key, understated production. The modern-dress setting in New York City of the 1990s is not a stone-built castle, but the glassplated luxury of the Elsinore Hotel, close to Times Square. Here, in the wake of his brother's death, having married the widowed Gertrude, the urbane and criminal CEO Claudius, played by Kyle MacLachlan, presides over the family corporate empire. In a modern representation of the usurper king, this Claudius comes across as a calmly self-possessed, impeccably well- 
mannered, and utterly ruthless combination of legitimate corporate $\mathrm{CEO}$ and mafia don.

Hamlet (Ethan Hawke), a moping, disaffected young man at odds with his world, first appears clad in a geeky hat more suggestive of a socially inept teenage computer buff, than of the noble prince of Denmark. We see him spending a great deal of time during the film hunched over a desktop, or mooching about in downtown video stores, preoccupied with his electronic gadgets. He lives surrounded by screens, on which at times his own soliloquies are projected back to him in the enclosed space of his room.

Almereyda's vision is, indeed, one of a world immersed in and conditioned by the apparatus of late twentieth-century technology. The ghost appears as a figure from occult movies, making his first appearance on the screens of CCTV cameras. The characters communicate often by landline phone. Hamlet leaves his parting shot to Ophelia, 'Get thee to a nunnery', as a message on her answer machine. In Ophelia's mad scene, the flowers she hands out to those around her are pictures of flowers on Polaroid photo prints. When, on the instructions of her father and of Claudius, Ophelia is sent to spy on Hamlet, she is equipped with a microphone hidden under her clothing. The play within a play, with its allusion to murder and usurpation, is presented as a videotape, shown to Claudius, Gertrude, and the rest of the family. Claudius' death is announced on television, by the well-known broadcaster, Robert Mc Neill, of the McNeill-Lehrer News Hour.

For all its ingenuity, or perhaps to some extent because of it, some viewers may feel that Almereyda's production lacks in intensity what it gives in abundance to 'relevance' in the twentieth-century setting. The relationship between Hamlet and Ophelia in particular between this callow, moody technophile and this nice, well-brought-up Catholic girl, seems hardly passionate enough to motivate Hamlet's rage when he finds her to be complicit in spying on him, or to make credible his outburst at her graveside: 'I loved Ophelia; forty thousand brothers / could not, with all their quantity of love / make up my sum'.

Hamlet's relationship with Horatio in this production is more convincing, giving us a male friendship we can believe in, from Horatio's first appearance to tell Hamlet about the ghost, through his helpful gesture in bringing his friend back into town from the airport by motorbike, when he returns from England. He bids a moving farewell to Hamlet as he dies, in his delivery of the line, 'Goodnight, sweet prince'. More problematic, however, is the presence of Horatio's girlfriend Marcella (a stand-in for the sentry Marcellus in the early scenes), but who is then a nonspeaking character accompanying Horatio throughout the rest of the film. It is difficult to see what purpose her presence serves.

Almereyda's Rosencrantz and Guildenstern (Steve Zahn and Dechen Thurman) are convincingly sleazy. We are not surprised to see them meeting with Hamlet to drink in a dimly-lit bar, their conversation partly muffled by loud background music, as they try unsuccessfully to extract information from him. These two would, one feels, do anything for drug money.

One of the most effective aspects of this production - apart from the highly convincing portrayal of Claudius, previously mentioned - is the relationship between Ophelia and Polonius her father, played by Bill Murray. This Ophelia (Julia Stiles) comes across as obedient but resentful, submitting to the manipulations of the adults in her world, with silent yet barely suppressed anger. As Polonius and Claudius instruct her in how to go about spying on Hamlet, we see her staring down into the hotel swimming pool where this scene takes place, and fantasising a desperate leap into its depths. The powerful visual image anticipates the manner of her later suicide. Another brilliant detail is the moment where Polonius lifts his daughter's foot onto a window sill and, almost absent-mindedly, talking all the while, ties the undone laces of her trainer, exactly as if she were a five-year-old. To her father, this Ophelia is still a child, and he knows what is best for her. Ophelia's sullen compliance with his wishes makes her mad scene, in which she screams her outrage at the world's cruelty, and which is overheard by the stunned bystanders on a public staircase, all the more shocking. Her drowning, not in a river, but in a public fountain, is deeply poignant. She floats in the shallow water with the box containing Hamlet's love letters to her floating nearby. Her body is pulled out by an anonymous New York cop, for whom such suicides must be a regular, if tragic, event in his mundane work.

For all its flaws, Almereyda's version of Hamlet has powerful moments. It remains an interesting experiment, compelling to watch, often surprising us by its sheer inventiveness.

\section{CONCLUSION}

In the past few years, more cinema adaptations of Shakespeare's play have appeared - notably a version directed by Dick Douglass in 2017; and a more adventurous production, a meta-theatrical piece directed by Taylor Myers and Dan Hasse 2019. The latter, Hamlet in the Golden Vale, employs a framing device in which a group of actors rehearse at a medieval Irish castle, for a new production of Hamlet.

Hamlet, perhaps more than any other Shakespeare character in film history, has fascinated successive screen audiences, and challenged the creative ingenuity of many distinguished directors and 
actors. We may be fairly sure that he will do so for generations yet to come.

\section{REFERENCES}

1. Shakespeare Quarterly, July 1952, 3(3), 227

2. The Complete Plays of Shakespeare - The Life of King Henry the Fifth.(2011). "Act I, Prologue". Lines 9-15 + 24 .

3. Danby, J.F. (1965). Elizabethan and Jacobean Poets. London: Faber \& Faber, 128.

4. Buchanan, J. (2009). Shakespeare on Silent Film: An Excellent Dumb Discourse. New York: CUP.

5. Gade, S. (1921). Hamlet: the Drama of Vengeance. https://www.youtube.com/watch?v=oz7aoVcRI58. Dec 21, 2014.

6. Howard, Tony. (2007). Women as Hamlet: Performance and Interpretation in Theatre, Film and Fiction. Cambridge: CUP. pp. 1-5.

7. Vining, E.P. (1881). The Mystery of Hamlet. Philadelphia: J.B. Lippincott \& Co.
8. Barker, F. (1953). The Oliviers. London: Hamish Hamilton, 259-260.

9. Donaldson, P.(1987). 'Olivier, Hamlet and Freud', in Cinema Journal, 2.64, 22-48.

10. Olivier, L. (1982). Confessions of an Actor. United Kingdom: Simon \& Schuster.

11. Shulman, M.(1985). Quoted in Robert Tanitch, Olivier. New York: Abbeville Press.

12. Kozintsev, G. (1966). Shakespeare, Time and Conscience. Transl. Joyce Vining. New York: Hill \& Wang.

13. Crowl, S. (2000). "Flamboyant Realist: Kenneth Branagh". In Jackson Russell (ed.) The Cambridge Companion to Shakespeare on Film. England: CUP, 225-228.

14. Mitchell, E. (2000). "Hamlet: A Simpler Melancholy in a Different Danemark". New York Times.

https://archive.nytimes.com/www.nytimes.com/libr ary/film/051200hamlet-film-review.html. 